\title{
The Neurobiology of Binge-Like Ethanol Drinking: Evidence from Rodent Models
}

\author{
Gretchen M. Sprow ${ }^{\mathrm{a}}$ and Todd E. Thiele $\mathrm{a}^{\mathrm{a}, \mathrm{b},{ }^{*}}$ \\ aDepartment of Psychology, University of North Carolina, Chapel Hill, NC 27599-3270 \\ ${ }^{b}$ Bowles Center for Alcohol Studies, University of North Carolina, Chapel Hill, NC 27599-3270
}

\section{Abstract}

Binge alcohol (ethanol) drinking is a destructive pattern of ethanol consumption that may precipitate ethanol dependence, a chronic, debilitating, and prevalent health problem. While an abundance of research has focused on the neurochemical underpinnings of ethanol dependence, relatively little is known about the mechanisms underlying the heavy consumption characteristic of binge ethanol drinking. Recently, a simple preclinical model termed "drinking in the dark" (DID) was developed to examine binge-like ethanol consumption in a rodent population. This assay capitalizes on the predisposition of $\mathrm{C} 57 \mathrm{BL} / 6 \mathrm{~J}$ mice to voluntarily consume substantial quantities of a high concentration ( $20 \% \mathrm{v} / \mathrm{v})$ ethanol solution, resulting in pharmacologically relevant blood ethanol concentrations (BECs). This review provides a comprehensive overview of recent literature utilizing this model to investigate the neuromodulatory systems that may influence binge ethanol drinking. Studies examining the glutamatergic and opioidergic systems not only provide evidence for these systems in the modulation of binge-like ethanol consumption, but also suggest this preclinical model has predictive validity and may be an appropriate tool for screening novel pharmacological compounds aimed at treating binge ethanol drinking in the human population. Additionally, this review presents evidence for the involvement of the GABAergic, dopaminergic, nicotinic, and endocannabinoid systems in modulating binge-like ethanol consumption. Finally, recent evidence shows that corticotropin-releasing factor (CRF), agouti-related protein (AgRP), neuropeptide $\mathrm{Y}$ (NPY), and ghrelin are also implicated as impacting this pattern of ethanol consumption.

\section{Keywords}

ethanol; binge; DID; C57BL/6J

\section{Introduction}

Alcohol (ethanol) dependence is a debilitating and costly health problem affecting many Americans and their families each year, and is one of the top preventable causes of death in the world $[1,2]$. As such, the neurochemical pathways underlying this disorder are currently the subject of intense investigation. Traditionally, preclinical research into the molecular

\footnotetext{
(c) 2012 Elsevier Inc. All rights reserved.

*Address correspondence to: Todd E. Thiele, Ph.D., Department of Psychology, CB\#3270, University of North Carolina, Chapel Hill, NC 27599-3270, USA, Phone: 919-966-1519; Fax: 919-962-2537; thiele@unc.edu.

Publisher's Disclaimer: This is a PDF file of an unedited manuscript that has been accepted for publication. As a service to our customers we are providing this early version of the manuscript. The manuscript will undergo copyediting, typesetting, and review of the resulting proof before it is published in its final citable form. Please note that during the production process errors may be discovered which could affect the content, and all legal disclaimers that apply to the journal pertain.
} 
underpinnings of alcoholism has utilized models of chronic ethanol drinking; to date, far less attention has been focused on binge ethanol drinking, a pattern of behavior that may emerge prior to, and contribute to the development of, ethanol dependence.

The National Institute on Alcohol Abuse and Alcoholism (NIAAA) defines an ethanol 'binge' as a pattern of drinking that produces blood ethanol concentrations (BECs) greater than $0.08 \%(80 \mathrm{mg} / \mathrm{dl})$ [3]. Typically, the pattern of drinking required to produce a BEC of this level is about 5 and 4 drinks in a 2-hour period for the average adult male and female, respectively. Although popular media generally associates this pattern of drinking with a younger demographic, most notably young college students, binge ethanol consumption is also prevalent among the adult population [4]. Indeed, a majority of binge drinking episodes in the United States involve adults over the age of 26 [5]. A substantial literature has associated binge ethanol drinking with both negative short- and long-term health and social consequences. For example, binge drinking has been linked with not only a decrease in general health, but also a number of specific health risks, including hypertension and type 2 diabetes [6, 7]. Additionally, binge ethanol drinking has been linked with an increased proclivity to partake in risky behaviors, including unprotected sex and impaired driving [5, $8,9]$. Finally, recent studies have also indicated that binge ethanol drinking early in life is positively associated with an increased risk of developing ethanol dependence later in life $[8,10,11]$. By studying the neurobiological mechanisms that underlie binge ethanol drinking, it may be possible to understand, and thus develop pharmacological treatments aimed at preventing, the neuroplastic alterations that develop during the transition to an ethanol-dependent state.

\section{Binge Drinking: Preclinical Models}

Due to inherent species differences, it is unlikely that a single rodent model can be developed to fully characterize ethanol abuse disorders and dependence, multi-faceted and complex disorders with diverse physical and social consequences [2]. Thus much of the current work in the field relies on partial models to closely examine specific facets of these disorders. For example, two-bottle choice methods have been successfully used to examine ethanol preference, while self-administration and relapse models have been used to investigate mechanisms contributing to the motivation to seek and consume ethanol [12]. Indeed, while these and other protocols have proven extremely valuable in examining certain features of ethanol dependence, none of these models accurately address the defining characteristics of binge ethanol drinking. Additionally, many of these methods (most notably, self-administration models) require extensive training, the use of food and/or water deprivation, or sucrose fading techniques to elicit ethanol consumption. Finally, rodents in these models often do not consume enough ethanol (or enough ethanol over a short enough period of time) to generate behavioral and/or pharmacological intoxication [12]..

While no mouse model can perfectly model a human disorder, a rodent model of binge-like ethanol drinking should fulfill certain criteria in order to reliably translate to humans. Briefly, the animal should voluntarily and orally self-administer ethanol to a substantial degree and over a limited time frame, such that it generates a pharmacologically relevant BEC analogous to that specified by the NIAAA [3]. Additionally, the animal should consume the ethanol for post-ingestive intoxicating effects, and not simply for taste or caloric fulfillment. Binge drinking has been proposed as a pattern of behavior that may lead to, or be involved in the transition to, dependence; thus a model of binge drinking need not meet all of the requirements of a broader model of ethanol dependence, such as the expression of tolerance or the presentation of withdrawal symptoms [13-15]. 
Several currently utilized models fulfill some, but not all, of the criteria for a model of binge-like ethanol drinking. For example, repeated intragastric delivery of a high dose of ethanol (e.g., $5 \mathrm{~g} / \mathrm{kg}$ ) has been a widely-used and validated as a technique that results in pharmacological and behavioral intoxication [16]. In a recent study, this technique was used to examine alterations in adult cholinergic genes following adolescent intragastric delivery of ethanol sufficient to achieve staggeringly high BECs (nearly $300 \mathrm{mg} / \mathrm{dl}$ ) [17]. This intragastric method of inducing high ethanol exposure in rodents is valuable in many ways, including the ability to both precisely control the amount of ethanol administered as well as ensure all animals achieve a pharmacologically relevant BEC. Intragastric methods of ethanol delivery are thus well suited for studies in which the focus is the neurobiological response to a high dose of orally administered ethanol; however, this method is perhaps not the most appropriate for modeling voluntary human ethanol consumption.

The scheduled high alcohol consumption (SHAC) protocol is another useful procedure that has been repeatedly shown to elicit high levels of ethanol drinking (and corresponding high BECs, often reaching over $100 \mathrm{mg} / \mathrm{dl}$ ) [18]. Indeed, this procedure has yielded an abundance of information regarding the role of opioidergic, glutamatergic, and GABAergic systems in high ethanol consumption [19-21]. However, despite the reliable high amounts of ethanol consumption garnered with this model, the SHAC procedure relies heavily on fluid restriction, often restricting fluid access for the majority of the day: in some cases, total fluid access is restricted to just 90-min per day. Thus, while this procedure yields high levels of ethanol consumption, it relies on an unnatural and stressful manipulation to do so. These aforementioned techniques, as well as others beyond the scope of this review, induce high levels of ethanol consumption but are similar in that they rely upon elaborate and artificial means of garnering high BECs - for example, bypassing the animal's choice to consume via intragastric delivery, or severely restricting total fluid access. Several recent studies have also taken advantage of an adapted intermittent access two-bottle choice procedure whereby both rats [22] and mice [23] voluntarily consume large amounts of 20\% ethanol (and achieve pharmacologically relevant BECs). Under this procedure, animals are given $24 \mathrm{~h}$ access to a $20 \%$ ethanol solution every other day, typically three sessions per week. Mice undergoing this procedure show signs of ethanol withdrawal (as measured by handling induced convulsions [23]. Further, both Naltrexone and acamprosate significantly reduced $20 \%$ ethanol consumption in rats under this intermittent access protocol [22]. This procedure, while a reliable method of inducing excessive drinking leading to dependencelike behaviors, utilizes long periods of ethanol deprivation and extended periods of ethanol consumption; as the NIAAA definition of a binge typically translates to 4-5 drinks in a twohour period for the average adult [3], this extended access may not be the most appropriate method for modeling binge-like ethanol consumption.

\section{Drinking in the Dark (DID)}

In the past several years, a simple mouse model termed "drinking in the dark" has gained acceptance as a robust model of binge-like ethanol drinking that consistently results in both pharmacologically relevant BECs and signs of behavioral intoxication [24, 25]. This protocol has a number of inherent advantages over other models of binge ethanol drinking. First, DID capitalizes on the natural nocturnal ingestive behavior of mice, negating the need for any kind of fluid restriction to induce drinking [26]. Thus, presentation of an ethanolcontaining solution during the early phase of the dark cycle (when mice are most active) to a strain of mice (typically C57BL/6J) genetically predisposed to voluntarily consume ethanol, reliably generates BECs of greater than $80 \mathrm{mg} / \mathrm{dl}$ (and typically, greater than $100 \mathrm{mg} / \mathrm{dl}$ ), thereby exceeding the guidelines as set by the NIAAA [3]. Although the motivation for the C57BL/6J mice to consume high amounts of ethanol under the DID protocol is unclear, mice achieving BECs of greater than $100 \mathrm{mg} / \mathrm{dl}$ have been shown to demonstrate behavioral 
signs of intoxication as demonstrated on both the balance beam and accelerating rotarod [25]. Additionally, High Drinking in the Dark (HDID) mice (generated by the intercrossing of 8 inbred strains, including C57BL/6J), have been selectively bred to achieve high BECs following binge-like ethanol consumption of a $20 \%$ ethanol solution [27, 28]. These mice will no doubt prove extremely useful in examining the neurobiological correlates of bingelike ethanol consumption.

Although the majority of this review focuses on DID as a mouse model of binge-like ethanol drinking, a modified DID protocol has also been successfully used to model binge-like ethanol drinking in rats (see section 5 below). One potential caveat to the DID protocol is that it relies heavily on the well-established predisposition of C57BL/6J mice to more readily consume ethanol than other, low-ethanol-drinking strains (such as the DBA/2J), thus potentially reducing the ability of this protocol to fully model the genetic diversity seen in ethanol drinkers. However, this characteristic may make DID particularly useful in modeling binge-like ethanol consumption in individuals with a similar genetic predisposition to heavy ethanol consumption (and potentially a predisposition to the development of ethanol dependence). Additionally, as noted by Rhodes et al. (2007) and observed elsewhere, there is a great deal of variation within this high-drinking strain in regards to the amount of ethanol consumed and the BECs achieved, potentially suggesting an epigenetic influence on the high amount of ethanol consumed with this protocol [25, 29].

In the typical DID procedure, the homecage water bottle of individually housed C57BL/6 J mice is replaced with a bottle containing $20 \%$ (v/v) ethanol for 2-h, 3-h after the beginning of the dark cycle, for 3 days. On the fourth day, the same procedure is followed, except that the ethanol-containing bottle is left on the cage for 4-h [24]. It is important to note that with this procedure, mice will voluntarily consume a relatively high concentration (typically $20 \%, v / v)$ of ethanol without requiring any training or prior exposure, and that this procedure does not require fluid restriction or a sucrose fading procedure [24]. In fact, while the water bottle is commonly removed during the 2 -h to 4 -h procedure, Rhodes et al. (2007) showed that mice drank similar amounts of ethanol with or without water available, although mice with concomitant access to water achieved BECs approximately $40 \%$ lower than those without simultaneous water access [25]. As the mice drink similar amounts of ethanol regardless of the presence of water, this suggests that thirst is not a motivating factor in generating high ethanol intake; additionally, the lower BECs achieved by mice with access to both ethanol and water may be explained by the dilution of the ethanol in both the stomach and blood by the water [25].Importantly, research from our laboratory has demonstrated that the excessive drinking established with the DID procedure does not result from fulfilling a caloric need, as administration of neither the orexigenic peptide ghrelin nor the anorectic protein leptin significantly altered ethanol consumption using this procedure, nor did food restriction alter the level of binge-like drinking [30]. These findings suggest that the high level of ethanol consumption is likely due to other, post-ingestive, effects.

In addition to being a simple technique that can serve as a high-throughput screening mechanism, the DID procedure is advantageous because its basic tenets are easily adaptable to accommodate various experimental demands. For example, the number of days in a single DID cycle can be extended in order to allow sufficient habituation to handling and other procedures related to delivery of a drug of interest [31]. Likewise, the duration of a single cycle can be shortened in order to meet experimental restrictions, as long as certain basic guidelines (i.e., limited access beginning 3-hr into the dark cycle) are held constant [32]. Further, as each 'cycle' of binge-like ethanol drinking is typically only four days long, examining the effect of repeated cycles of binge-like ethanol consumption is quite practical. Finally, the DID procedure lends itself well to examining the specificity of effects of pharmacological compounds on binge-like ethanol drinking, as concurrent water, sucrose, 
and other controls are simple to perform. Together, this flexible methodology, combined with the strength and consistency of drinking behavior and BECs achieved, make DID an extremely beneficial and powerful research tool for examining a rodent correlate of human ethanol binge drinking.

\section{DID with C57BL/6J Mice: The Neurobiology of Binge-Like Ethanol Drinking}

The DID model has been influential in examining both the behavioral aspects as well as the neurobiological underpinnings of binge-like ethanol consumption. As such, DID has been widely used to investigate the role of neuromodulatory systems that may impact this pattern of consumption. See Table 1 for a summary of the results that are reviewed below.

\subsection{Glutamatergic system}

A substantial literature has confirmed an integral role of the glutamatergic system in ethanol dependence: acamprosate, which is thought to act as a functional glutamate antagonist, is one of a select few drugs accepted for pharmacological treatment of ethanol dependence [33]. Indeed, a meta-analysis of 13 clinical trials confirmed the efficacy of acamprosate as a therapeutic approach for maintaining abstinence [34]. In a recent preclinical study, intraperitoneal (i.p.) administration of both acamprosate and 6-Methyl-2-(phenylethynyl) pyridine (MPEP; a metabotropic glutamate 5 receptor (mGLuR5) antagonist) dosedependently reduced binge-like ethanol consumption using the 2-h (acamprosate) or 4-h (MPEP) DID procedure [35]. While select doses of acamprosate were able to selectively decrease ethanol intake by approximately 20\%, MPEP was more potent and had a longer duration of action [35]. Together, these data not only suggest a role for mGluR signaling in modulating excessive (binge) ethanol intake, but also suggest that the DID protocol has predictive validity. Thus DID may be an appropriate tool for screening novel pharmacological compounds aimed at treating binge ethanol consumption.

\subsection{GABAergic system}

The DID procedure has also been valuable in exploring the role of the GABAergic system in binge-like ethanol drinking. In a modified 7-d DID procedure, both systemic and posterior ventral tegmental area (VTA) administration (but not anterior VTA administration) of the imidazobenzodiazepine derivative Ro15-4513, a benzodiazepine partial inverse agonist, dose-dependently reduced $20 \%$ ethanol consumption (and related BECs), whereas consumption of a 5\% sucrose solution was not affected [36]. Likewise, in a modified 5-d DID procedure, systemic baclofen (a GABA $A_{B}$ agonist) dose dependently increased, while systemic muscimol (a potent $\mathrm{GABA}_{\mathrm{A}}$ agonist) decreased ethanol intake without affecting water consumption [37]. A separate study localized the effect of baclofen to the anterior VTA [38]. Together, these data suggest involvement of the GABAergic system of the VTA in modulating binge-like ethanol consumption.

\subsection{Dopaminergic and opioidergic systems}

Both dopaminergic and opioidergic neurotransmitter systems have long been established as having integral involvement in drug and ethanol dependence [39, 40]. A recent critical study examined the involvement of these systems in the excessive ethanol consumption characteristic of binge ethanol consumption using the DID procedure. Naltrexone (a nonspecific competitive opioid receptor antagonist) and GBR 12909 (a dopamine reuptake blocker) dose-dependently reduced ethanol consumption in a modified 2-d DID procedure [41]. While the doses of Naltrexone that reduced ethanol consumption had no effect on water or sugar water consumption, GBR 12909 also reduced sugar water consumption. More 
recently, mice lacking the long version of the dopamine 2 receptor (D2R) drank more $20 \%$ ethanol than their wild-type counterparts in a DID procedure, suggesting a role for specific dopamine receptors in excessive ethanol intake [42]. Together these results further implicate both the opioidergic and dopaminergic systems in modulating excessive ethanol consumption, such as that seen in binge ethanol drinking. Additionally, these results further confirm the predictive validity of the DID model, as Naltrexone, known to reduce ethanol consumption in human alcoholics, also reduced ethanol binge-like ethanol consumption in C57BL/6J mice.

\subsection{Nicotinic system}

The comorbidity of nicotine and ethanol abuse has been well documented, yet much about this complex relationship remains unclear [43, 44]. Neuronal nicotinic acetylcholine receptors (nAChRs) have been found to partially mediate the reinforcing properties of ethanol, and the nicotinic receptor partial agonist varenicline has been found to selectively reduce ethanol seeking and consumption in rodent models [45, 46]. Recent studies have also implicated nAChRs in binge ethanol consumption using modified (2-d) versions of the DID procedure. In the first study, systemic mecamylamine hydrochloride (mecamylamine; a nonspecific and noncompetitive nAChR antagonist) reduced $20 \%$ ethanol consumption and related BECs relative to saline-treated control mice [47]. This effect was specific to ethanol, as mecamylamine did not affect sucrose consumption, and supports previous data showing that mecamylamine, when injected into the VTA, reduces ethanol consumption in highdrinking Wistar rats [48]. Interestingly, systemic treatment with nicotinic agonists cytisine and nicotine also reduced binge-like ethanol consumption, an effect possibly attributable to the enormity and complexity of the nAChR subunit system [47]. Finally, subcutaneous administration of the nicotinic alkaloid lobeline, which acts as a mixed agonist-antagonist at nAChRs, also reduced $20 \%$ ethanol consumption in a 2-d DID procedure without significantly affecting sucrose or water consumption [32]. These results suggest that the relationship between nicotine and ethanol use may begin early in, or prior to, the development of ethanol dependence.

\subsection{Endocannabinoid system}

An abundance of both preclinical and clinical literature has suggested both direct and indirect roles of the endocannabinoid system in ethanol dependence (for a detailed review, see [49]). Recent evidence has also implicated the cannabinoid receptor system in modulating binge-like ethanol consumption by C57BL/6J mice. Systemic injection of the synthetic cannabinoid agonist WIN 55-313 dose-dependently modulated ethanol consumption of C57BL/6J mice in a modified (7-d) DID protocol [31]. While a low dose of WIN 55-313 significantly increased initial ethanol consumption, higher doses significantly decreased consumption, an effect likely due to nonspecific locomotor effects of a high dose of the drug. However, bilateral infusion of the compound into the posterior VTA also altered the time course of ethanol consumption throughout the binge session. Together, these results suggest that the endocannabinoid system may not only be involved during ethanol dependence, but also during binge ethanol drinking prior to the development of dependence.

\subsection{Corticotropin-releasing factor (CRF)}

A wealth of literature has implicated a role for the CRF system in ethanol's effects following both acute ethanol exposure as well as during procedures designed to model ethanol dependence $[39,50,51]$. Work from our laboratory and others has expanded this literature to show that the CRF system also plays an integral role in modulating binge-like ethanol consumption. First, systemic administration of butyl-[2,5-dimethyl-7-(2,4,6trimethylphenyl)-7H-pyrrolo[2,3-d]pyrimidin-4-yl]-ethylamine (CP-154, 526), a potent and selective agonist of the CRF type-1 receptor (CRF1R), attenuated binge-like ethanol 
consumption in C57BL/6J mice using the 4-d DID procedure [52]. The importance of CRFR signaling in binge-like ethanol consumption was further confirmed as intracerebroventricular (i.c.v.) infusion of $a$-helical $\mathrm{CRF}_{9-41}$, a nonselective CRFR antagonist, attenuated and a CRF type-2 receptor (CRF2R) agonist Urocortin-3 (Ucn3) blunted binge-like ethanol consumption [53]. Importantly, CRF1R antagonism did not alter non-binge-like ethanol consumption using a modified DID protocol. When ethanol was presented for 4-h, 3-h into the dark cycle for four consecutive days, mice achieved BECs of under $40 \mathrm{mg} / \mathrm{dl}$; CRF1R antagonism did not significantly alter the moderate level of ethanol consumption using this modified protocol, suggesting the CRF system plays an important role specifically in the excessive ethanol intake seen with binge-like ethanol consumption [52].

Further confirming involvement of the CRF system in modulating excessive ethanol intake, microinjection of the CRF agonist Urocortin 1 (Ucn1) into the lateral septum in a slightly modified DID procedure significantly decreased ethanol consumption [54]. Finally, more recent work used the DID procedure to assess binge-like ethanol drinking in mutant mice lacking normal production of either CRF, CRF1R, CRF2R, or Ucn1 [55]. Here again, the CRF1R was affirmed as playing a critical role in modulating excessive ethanol consumption. Together, the current research strongly suggests that the CRF system is involved in high (but not low or moderate) ethanol consumption, which may in turn contribute to the development of ethanol dependence.

\subsection{Melanocortin (MC) Peptides}

As previous literature has indicated an involvement of the MC receptor (MCR) system in modulating neurobiological responses to ethanol and ethanol intake [56, 57], our laboratory investigated the role of agouti-related protein (AgRP), an endogenous MCR antagonist, in binge-like ethanol consumption using the standard 4-d DID procedure. [58]. In this study, mutant mice lacking normal production of AgRP showed blunted binge-like ethanol consumption (and a related decrease in BEC) relative to wild-type littermates [58]. Current work is underway to assess the role of other MC-related peptides (e.g., a-MSH) in the modulation of binge-like ethanol consumption.

\subsection{Neuropeptide Y (NPY)}

Recent work from our laboratory has provided evidence for a role of NPY signaling in modulating binge-like ethanol drinking in C57BL/6J mice using the 4-d DID procedure previously described [29]. First, i.c.v. infusion of NPY, an NPY Y1 (Y1R) receptor agonist, and a Y2R antagonist significantly blunted binge-like ethanol consumption.

Immunohistochemical and electrophysiological approaches further implicated NPY signaling in modulating this excessive ethanol consumption, as a history of binge-like drinking significantly altered NPY, Y1R, and Y2R immunoreactivity in the central nucleus of the amygdala (CeA), and increased NPY-induced inhibition of GABAergic transmission in slice preparations of the CeA [29]. Interestingly, similar doses of centrally administered NPY have previously been ineffective at altering low-level, non-binge-like ethanol consumption (using a $2 \mathrm{hr}$ voluntary consumption protocol) [59]. Taken together, these results strongly suggest a role for NPY signaling in specifically modulating the excessive consumption characteristic of binge ethanol drinking, potentially contributing to the development of ethanol dependence.

\subsection{Ghrelin}

As previously indicated, systemic administration of the orexigenic peptide ghrelin did not significantly alter $20 \%$ ethanol consumption using the DID procedure [30]. However, in a modified 7-d DID procedure, systemic injection of the ghrelin receptor antagonist, D-Lys3- 
GHRP-6 not only caused a significant decrease in $20 \%$ ethanol consumption, but also decreased ethanol preference in a modified 2-bottle DID procedure [60]. Together, these results suggest that future work is needed to clarify the role ghrelin may play in excessive ethanol intake, especially considering the important role this hormone is suggested to play in obesity and other eating disorders [61].

\section{DID with Rats: The Neurobiology of Binge-Like Ethanol Drinking}

Although many investigations into the neurobiological underpinning of binge ethanol consumption rely on a variation of a standard DID procedure using C57BL/6J mice [24], several recent studies have taken advantage of ethanol-preferring rat strains using a similar protocol termed drinking-in-the-dark-multiple-schedule-access (DID-MSA) [15, 62, 63]. In this procedure, ethanol-preferring P-rats (which, like C57BL/6J mice, will voluntarily consume a high-concentration ethanol solution) have concurrent access to water, $15 \%$, and $30 \%$ ethanol: while water is available ad libitum, ethanol is available for three $1-\mathrm{h}$ sessions during the dark cycle, with each session separated by 2 -h periods of ethanol abstinence [15, 64]. Interestingly, unlike the standard mouse DID protocol in which ethanol is presented 3-h into the dark cycle, the maximum ethanol consumption using the DID-MSA procedure occurs when ethanol is first presented immediately after lights out [63].

This DID-MSA procedure has been useful in examining how continuous ethanol exposure and binge-like ethanol exposure differentially affect the expression of proteins involved in a multitude of intracellular functions within brain reward neurocircuitry [65]. Additionally, a more recent study examined changes in gene expression in regions of the extended amygdala following binge-like ethanol exposure: results indicated that binge- like ethanol drinking produces region-dependent alterations in gene expression within the nucleus accumbens shell and the central nucleus of the amygdala, two areas previously implicated in mediating the neurobiological effects of ethanol [62]. A modified DID-MSA protocol using Sprague-Dawley rats (using temporary water restriction to enhance ethanol consumption), has also been combined with self-administration procedures to examine how the P2rx4 gene, which codes for a receptor in the purinergic system of ligand-gated ion channels, influences the behavioral effects of ethanol [66]. Purinergic type 2 receptors have previously been revealed as important targets for ethanol action and have been suggested to be important mediators of ethanol-induced effects $[67,68]$. Though the standard mouse DID procedure is currently much more common than the rat DID-MSA model, DID-MSA holds great potential for future studies; specifically, this rat DID model may prove exceptionally useful when combined with self-administration testing and other assays that are notoriously difficult to perform using mice.

\section{Conclusions}

As this brief review has demonstrated, the DID procedure has been extremely beneficial in examining the central neurochemical pathways that modulate binge-like ethanol drinking. This simple procedure reliably generates high levels of ethanol consumption and corresponding high, pharmacologically relevant BECs that exceed the criteria of a binge [3]. Additionally, this procedure provides several benefits above other currently utilized models of binge-like ethanol consumption, in that animals consistently and voluntarily consume high concentrations of ethanol without the need of fluid or food restriction or sucrose fading techniques. Using this technique, a great deal of information has been garnered about the involvement of GABAergic, glutamatergic, dopaminergic, and opioidergic systems in modulating binge-like ethanol consumption. Roles for the nicotinic, endocannabinoid, CRF, NPY, melanocortin, and ghrelin systems have also been suggested. In addition to examining the specific neurochemical systems outlined above, the flexible mouse DID model has also 
been used in a variety of other studies, beyond the scope of this review, including those that model prenatal binge-like ethanol exposure [69] and that examine the effects of ethanol dose-response self-administration patterns using cDNA [70].

Finally, research on binge-like ethanol consumption has suggested that different neural mechanisms may underlie binge-like and non-binge-like ethanol intake. For example, in the CRF studies mentioned above (see 4.6) CRF1R antagonism blunted binge-like ethanol consumption, but did not affect moderate, non-binge like ethanol consumption [52, 53], paralleling the observation that CRF receptor antagonists blunt excessive dependence-like ethanol consumption but fail to alter low-level consumption in non-dependent animals [71, 72]. The similarities between models of excessive binge-like ethanol drinking and dependence-like ethanol intake suggest that overlapping mechanisms may be present. Thus, it is possible that excessive binge-like drinking in non-dependent animals may trigger transient neurochemical alterations (e.g., increased CRF1R signaling) in critical pathways analogous to what occurs after the development of dependence. These transient neurochemical changes may motivate binge-like drinking as do permanent neurochemical changes in motivating dependence-induced drinking. Increased CRF1R signaling stemming from binge-like ethanol drinking may worsen and fail to "normalize" with repeated binge episodes, ultimately contributing to the transition to dependence, consistent with the allostasis model [73]. Clearly, much more work will be needed to verify this hypothesis, and studies employing procedures that model binge ethanol drinking may help clarify this important gap in the literature.

\section{Acknowledgments}

This work was supported by NIH grants AA013573, AA015148, AA017803, and AA019839.

\section{References}

1. CDC. Alcohol-attibutable deaths and years of potential life lost - United States, 2001. MMWR Morb Mortal Wkly Rep. 2004:866-70. [PubMed: 15385917]

2. Hines LM, Ray L, Hutchison K, Tabakoff B. Alcoholism: the dissection for endophenotypes. Dialogues Clin Neurosci. 2005; 7:153-63. [PubMed: 16262210]

3. NIAAA. NIAAA Newsletter. 2004. NIAAA council approves definition of binge drinking.

4. Nelson DE, Naimi TS, Brewer RD, Nelson HA. State alcohol-use estimates among youth and adults, 1993-2005. Am J Prev Med. 2009; 36:218-24. [PubMed: 19215847]

5. Naimi TS, Brewer RD, Mokdad A, Denny C, Serdula MK, Marks JS. Binge Drinking Among US Adults. JAMA: The Journal of the American Medical Association. 2003; 289:70-5. [PubMed: 12503979]

6. Fan AZ, Russell M, Stranges S, Dorn J, Trevisan M. Association of Lifetime Alcohol Drinking Trajectories with Cardiometabolic Risk. Journal of Clinical Endocrinology \& Metabolism. 2008; 93:154-61. [PubMed: 18029458]

7. Okoro CA, Brewer RD, Naimi TS, Moriarty DG, Giles WH, Mokdad AH. Binge drinking and health-related quality of life: do popular perceptions match reality? Am J Prev Med. 2004; 26:230 3. [PubMed: 15026103]

8. Miller JW, Naimi TS, Brewer RD, Jones SE. Binge Drinking and Associated Health Risk Behaviors Among High School Students. Pediatrics. 2007; 119:76-85. [PubMed: 17200273]

9. Naimi TS, Lipscomb LE, Brewer RD, Gilbert BC. Binge drinking in the preconception period and the risk of unintended pregnancy: implications for women and their children. Pediatrics. 2003; 111:1136-41. [PubMed: 12728126]

10. Hingson RW, Heeren T, Winter MR. Age of Alcohol-Dependence Onset: Associations With Severity of Dependence and Seeking Treatment. Pediatrics. 2006; 118:e755-e63. [PubMed: 16950966] 
11. Hingson RW, Heeren T, Winter MR. Age at drinking onset and alcohol dependence: age at onset, duration, and severity. Arch Pediatr Adolesc Med. 2006; 160:739-46. [PubMed: 16818840]

12. Spanagel R. Recent animal models of alcoholism. Alcohol Res Health. 2000; 24:124-31. [PubMed: 11199279]

13. Cicero, TJ. A critique of animal analogue of alcoholism. In: Majchrowichz, E.; Noble, P., editors. Biochemistry and pharmacology of ethanol. New York: Plenum Press; 1979. p. 533-60.

14. Lester D, Freed E. Criteria for an animal model of alcoholism. 1973; 1:103-7.

15. Bell RL, Rodd ZA, Smith RJ, Toalston JE, Franklin KM, McBride WJ. Modeling binge-like ethanol drinking by peri-adolescent and adult P rats. Pharmacol Biochem Behav. 2011; 100:90-7. [PubMed: 21824488]

16. Faingold, CL. Current Protocols in Neuroscience. John Wiley \& Sons, Inc; 2001. The Majchrowicz Binge Alcohol Protocol: An Intubation Technique to Study Alcohol Dependence in Rats.

17. Coleman LG Jr, He J, Lee J, Styner M, Crews FT. Adolescent Binge Drinking Alters Adult Brain Neurotransmitter Gene Expression, Behavior, Brain Regional Volumes, and Neurochemistry in Mice. Alcoholism: Clinical and Experimental Research. 2011; 35:671-88.

18. Finn DA, Belknap JK, Cronise K, Yoneyama N, Murillo A, Crabbe JC. A procedure to produce high alcohol intake in mice. Psychopharmacology (Berl). 2005; 178:471-80. [PubMed: 15765261]

19. Tanchuck MA, Yoneyama N, Ford MM, Fretwell AM, Finn DA. Assessment of GABA-B, metabotropic glutamate, and opioid receptor involvement in an animal model of binge drinking. Alcohol. 2011; 45:33-44. [PubMed: 20843635]

20. Szumlinski KK, Diab ME, Friedman R, Henze LM, Lominac KD, Bowers MS. Accumbens neurochemical adaptations produced by binge-like alcohol consumption. Psychopharmacology (Berl). 2007; 190:415-31. [PubMed: 17225170]

21. Cozzoli DK, Goulding SP, Zhang PW, Xiao B, Hu JH, Ary AW, et al. Binge drinking upregulates accumbens mGluR5-Homer2-PI3K signaling: functional implications for alcoholism. J Neurosci. 2009; 29:8655-68. [PubMed: 19587272]

22. Simms JA, Steensland P, Medina B, Abernathy KE, Chandler LJ, Wise R, et al. Intermittent access to $20 \%$ ethanol induces high ethanol consumption in Long-Evans and Wistar rats. Alcohol Clin Exp Res. 2008; 32:1816-23. [PubMed: 18671810]

23. Hwa LS, Chu A, Levinson SA, Kayyali TM, DeBold JF, Miczek KA. Persistent escalation of alcohol drinking in C57BL/6 J mice with intermittent access to $20 \%$ ethanol. Alcohol Clin Exp Res. 35:1938-47. [PubMed: 21631540]

24. Rhodes JS, Best K, Belknap JK, Finn DA, Crabbe JC. Evaluation of a simple model of ethanol drinking to intoxication in C57BL/6J mice. Physiol Behav. 2005; 84:53-63. [PubMed: 15642607]

25. Rhodes JS, Ford MM, Yu CH, Brown LL, Finn DA, Garland T Jr, et al. Mouse inbred strain differences in ethanol drinking to intoxication. Genes Brain Behav. 2007; 6:1-18. [PubMed: 17233637]

26. Ho A, Chin A. Circadian feeding and drinking patterns of genetically obese mice fed solid chow diet. Physiol Behav. 1988; 43:651-6. [PubMed: 3200922]

27. Crabbe JC, Spence SE, Brown LL, Metten P. Alcohol preference drinking in a mouse line selectively bred for high drinking in the dark. Alcohol. 2011; 45:427-40. [PubMed: 21194877]

28. Crabbe JC, Metten P, Rhodes JS, Yu CH, Brown LL, Phillips TJ, et al. A line of mice selected for high blood ethanol concentrations shows drinking in the dark to intoxication. Biol Psychiatry. 2009; 65:662-70. [PubMed: 19095222]

29. Sparrow AM, Lowery-Gionta EG, Pleil KE, Li C, Sprow GM, Cox BR, et al. Central Neuropeptide Y Modulates Binge-Like Ethanol Drinking in C57BL/6J Mice via Y1 and Y2 Receptors. Neuropsychopharmacology. in press.

30. Lyons AM, Lowery EG, Sparta DR, Thiele TE. Effects of food availability and administration of orexigenic and anorectic agents on elevated ethanol drinking associated with drinking in the dark procedures. Alcohol Clin Exp Res. 2008; 32:1962-8. [PubMed: 18782340]

31. Linsenbardt DN, Boehm SL 2nd. Agonism of the endocannabinoid system modulates binge-like alcohol intake in male C57BL/6J mice: involvement of the posterior ventral tegmental area. Neuroscience. 2009; 164:424-34. [PubMed: 19665522] 
32. Sajja RK, Rahman S. Lobeline and cytisine reduce voluntary ethanol drinking behavior in male C57BL/6J mice. Prog Neuropsychopharmacol Biol Psychiatry. 2011; 35:257-64. [PubMed: 21111768]

33. Heilig M, Egli M. Pharmacological treatment of alcohol dependence: target symptoms and target mechanisms. Pharmacol Ther. 2006; 111:855-76. [PubMed: 16545872]

34. Bouza C, Angeles M, Munoz A, Amate JM. Efficacy and safety of naltrexone and acamprosate in the treatment of alcohol dependence: a systematic review. Addiction. 2004; 99:811-28. [PubMed: 15200577]

35. Gupta T, Syed YM, Revis AA, Miller SA, Martinez M, Cohn KA, et al. Acute effects of acamprosate and MPEP on ethanol Drinking-in-the-Dark in male C57BL/6J mice. Alcohol Clin Exp Res. 2008; 32:1992-8. [PubMed: 18782337]

36. Melon LC, Boehm SL 2nd. GABAA receptors in the posterior but not anterior ventral tegmental area mediate Ro15-4513-induced attenuation of binge-like ethanol consumption in C57BL/6J female mice. Behav Brain Res. 2011; 220:230-7. [PubMed: 21320533]

37. Moore EM, Serio KM, Goldfarb KJ, Stepanovska S, Linsenbardt DN, Boehm SL 2nd. GABAergic modulation of binge-like ethanol intake in C57BL/6J mice. Pharmacol Biochem Behav. 2007; 88:105-13. [PubMed: 17698181]

38. Moore EM, Boehm SL 2nd. Site-specific microinjection of baclofen into the anterior ventral tegmental area reduces binge-like ethanol intake in male C57BL/6J mice. Behav Neurosci. 2009; 123:555-63. [PubMed: 19485562]

39. Koob GF. Alcoholism: allostasis and beyond. Alcohol Clin Exp Res. 2003; 27:232-43. [PubMed: 12605072]

40. Mendez M, Morales-Mulia M. Role of mu and delta opioid receptors in alcohol drinking behaviour. Curr Drug Abuse Rev. 2008; 1:239-52. [PubMed: 19630722]

41. Kamdar NK, Miller SA, Syed YM, Bhayana R, Gupta T, Rhodes JS. Acute effects of naltrexone and GBR 12909 on ethanol drinking-in-the-dark in C57BL/6J mice. Psychopharmacology (Berl). 2007; 192:207-17. [PubMed: 17273875]

42. Bulwa ZB, Sharlin JA, Clark PJ, Bhattacharya TK, Kilby CN, Wang Y, et al. Increased consumption of ethanol and sugar water in mice lacking the dopamine D2 long receptor. Alcohol. 2011; 45:631-9. [PubMed: 21803530]

43. Romberger DJ, Grant K. Alcohol consumption and smoking status: the role of smoking cessation. Biomed Pharmacother. 2004; 58:77-83. [PubMed: 14992787]

44. DiFranza JR, Guerrera MP. Alcoholism and smoking. J Stud Alcohol. 1990; 51:130-5. [PubMed: 2308350]

45. Steensland P, Simms JA, Holgate J, Richards JK, Bartlett SE. Varenicline, an alpha4beta2 nicotinic acetylcholine receptor partial agonist, selectively decreases ethanol consumption and seeking. Proc Natl Acad Sci U S A. 2007; 104:12518-23. [PubMed: 17626178]

46. Soderpalm B, Ericson M, Olausson P, Blomqvist O, Engel JA. Nicotinic mechanisms involved in the dopamine activating and reinforcing properties of ethanol. Behav Brain Res. 2000; 113:85-96. [PubMed: 10942035]

47. Hendrickson LM, Zhao-Shea R, Tapper AR. Modulation of ethanol drinking-in-the-dark by mecamylamine and nicotinic acetylcholine receptor agonists in C57BL/6J mice. Psychopharmacology (Berl). 2009; 204:563-72. [PubMed: 19247637]

48. Ericson M, Blomqvist O, Engel A Jr, SÃ đderpalm B. Voluntary ethanol intake in the rat and the associated accumbal dopamine overflow are blocked by ventral tegmental mecamylamine. European Journal of Pharmacology. 1998; 358:189-96. [PubMed: 9822883]

49. Erdozain AM, Callado LF. Involvement of the endocannabinoid system in alcohol dependence: the biochemical, behavioral and genetic evidence. Drug Alcohol Depend. 2011; 117:102-10. [PubMed: 21414731]

50. Li Z, Kang SS, Lee S, Rivier C. Effect of ethanol on the regulation of corticotropin-releasing factor (CRF) gene expression. Mol Cell Neurosci. 2005; 29:345-54. [PubMed: 15914027]

51. Koob GF. A role for brain stress systems in addiction. Neuron. 2008; 59:11-34. [PubMed: 18614026] 
52. Sparta DR, Sparrow AM, Lowery EG, Fee JR, Knapp DJ, Thiele TE. Blockade of the corticotropin releasing factor type 1 receptor attenuates elevated ethanol drinking associated with drinking in the dark procedures. Alcohol Clin Exp Res. 2008; 32:259-65. [PubMed: 18162072]

53. Lowery EG, Spanos M, Navarro M, Lyons AM, Hodge CW, Thiele TE. CRF-1 antagonist and CRF-2 agonist decrease binge-like ethanol drinking in C57BL/6J mice independent of the HPA axis. Neuropsychopharmacology. 2010; 35:1241-52. [PubMed: 20130533]

54. Ryabinin AE, Yoneyama N, Tanchuck MA, Mark GP, Finn DA. Urocortin 1 microinjection into the mouse lateral septum regulates the acquisition and expression of alcohol consumption. Neuroscience. 2008; 151:780-90. [PubMed: 18164138]

55. Kaur S, Li J, Stenzel-Poore MP, Ryabinin AE. Corticotropin-Releasing Factor Acting on Corticotropin-Releasing Factor Receptor Type 1 is Critical for Binge Alcohol Drinking in Mice. Alcohol Clin Exp Res. 2011

56. Navarro M, Cubero I, Knapp DJ, Breese GR, Thiele TE. Decreased immunoreactivity of the melanocortin neuropeptide alpha-melanocyte-stimulating hormone (alpha-MSH) after chronic ethanol exposure in Sprague-Dawley rats. Alcohol Clin Exp Res. 2008; 32:266-76. [PubMed: 18162070]

57. Ploj K, Roman E, Kask A, Hyytia P, Schioth HB, Wikberg J, et al. Effects of melanocortin receptor ligands on ethanol intake and opioid levels in alcohol-preferring AA rats. Brain Res Bull. 2002; 59:97-104. [PubMed: 12379439]

58. Navarro M, Cubero I, Ko L, Thiele TE. Deletion of agouti-related protein blunts ethanol selfadministration and binge-like drinking in mice. Genes Brain Behav. 2009; 8:450-8. [PubMed: 19566712]

59. Thiele TE, Sparta DR, Fee JR, Navarro M, Cubero I. Central neuropeptide Y alters ethanolinduced sedation, but not ethanol intake, in C57BL/6 mice. Alcohol. 2003; 31:155-60. [PubMed: 14693264]

60. Kaur S, Ryabinin AE. Ghrelin receptor antagonism decreases alcohol consumption and activation of perioculomotor urocortin-containing neurons. Alcohol Clin Exp Res. 2010; 34:1525-34. [PubMed: 20586761]

61. Yi CX, Heppner K, Tschop MH. Ghrelin in eating disorders. Mol Cell Endocrinol. 2011; 340:29_ 34. [PubMed: 21453750]

62. McBride WJ, Kimpel MW, Schultz JA, McClintick JN, Edenberg HJ, Bell RL. Changes in gene expression in regions of the extended amygdala of alcohol-preferring rats after binge-like alcohol drinking. Alcohol. 2010; 44:171-83. [PubMed: 20116196]

63. Bell RL, Rodd ZA, Lumeng L, Murphy JM, McBride WJ. The alcohol-preferring P rat and animal models of excessive alcohol drinking. Addict Biol. 2006; 11:270-88. [PubMed: 16961759]

64. Bell RL, Kimpel MW, McClintick JN, Strother WN, Carr LG, Liang T, et al. Gene expression changes in the nucleus accumbens of alcohol-preferring rats following chronic ethanol consumption. Pharmacol Biochem Behav. 2009; 94:131-47. [PubMed: 19666046]

65. Bell RL, Kimpel MW, Rodd ZA, Strother WN, Bai F, Peper CL, et al. Protein expression changes in the nucleus accumbens and amygdala of inbred alcohol-preferring rats given either continuous or scheduled access to ethanol. Alcohol. 2006; 40:3-17. [PubMed: 17157716]

66. Kosten TA. Pharmacologically targeting the P2rx4 gene on maintenance and reinstatement of alcohol self-administration in rats. Pharmacol Biochem Behav. 2011; 98:533-8. [PubMed: 21402096]

67. Ostrovskaya O, Asatryan L, Wyatt L, Popova M, Li K, Peoples RW, et al. Ethanol is a fast channel inhibitor of P2X4 receptors. J Pharmacol Exp Ther. 2011; 337:171-9. [PubMed: 21212160]

68. Xiao C, Zhou C, Li K, Davies DL, Ye JH. Purinergic type 2 receptors at GABAergic synapses on ventral tegmental area dopamine neurons are targets for ethanol action. J Pharmacol Exp Ther. 2008; 327:196-205. [PubMed: 18583548]

69. Boehm SL 2nd, Moore EM, Walsh CD, Gross CD, Cavelli AM, Gigante E, et al. Using drinking in the dark to model prenatal binge-like exposure to ethanol in C57BL/6J mice. Dev Psychobiol. 2008; 50:566-78. [PubMed: 18683190] 
70. Mulligan MK, Rhodes JS, Crabbe JC, Mayfield RD, Adron Harris R, Ponomarev I. Molecular profiles of drinking alcohol to intoxication in C57BL/6J mice. Alcohol Clin Exp Res. 2011; 35:659-70. [PubMed: 21223303]

71. Funk CK, O'Dell LE, Crawford EF, Koob GF. Corticotropin-releasing factor within the central nucleus of the amygdala mediates enhanced ethanol self-administration in withdrawn, ethanoldependent rats. J Neurosci. 2006; 26:11324-32. [PubMed: 17079660]

72. Funk CK, Zorrilla EP, Lee MJ, Rice KC, Koob GF. Corticotropin-releasing factor 1 antagonists selectively reduce ethanol self-administration in ethanol-dependent rats. Biol Psychiatry. 2007; 61:78-86. [PubMed: 16876134]

73. Koob GF, Le Moal M. Drug addiction, dysregulation of reward, and allostasis. Neuropsychopharmacology. 2001; 24:97-129. [PubMed: 11120394] 


\section{Highlights}

Over the last several years, a large focus of pre-clinical research has been aimed at the neurobiology of ethanol dependence.

A growing body of literature is emerging investigating the neurobiology of bingelike ethanol drinking in non-dependent animals.

The present paper overviews recent findings on the neurobiology of binge-like ethanol drinking in animals models. 
Table 1

Summary of DID Studies: Neurobiological Mechanisms of Binge-like Ethanol Consumption

\begin{tabular}{|c|c|c|c|}
\hline System Examined & Major Finding & DID Procedure Details & Study \\
\hline Glutamate & $\begin{array}{l}\text { Acamprosate (i.p.) and MPEP (i.p) } \downarrow 20 \% \\
\text { EtOH consumption }\end{array}$ & $\begin{array}{l}\text { 2-d procedure; 2-h (Acamprosate) and 4-h (MPEP) } \\
\text { EtOH access }\end{array}$ & {$[35]$} \\
\hline \multirow[t]{3}{*}{ GABAergic } & $\begin{array}{l}\text { Ro15-4513 (i.p.; intra-VTA) } \downarrow 20 \% \text { EtOH } \\
\text { consumption }\end{array}$ & 7-d procedure; 2-h EtOH access & {$[36]$} \\
\hline & $\begin{array}{l}\text { Baclofen (i.p.) } \uparrow, \text { muscimol (i.p.) } \downarrow 20 \% \mathrm{EtOH} \\
\text { consumption }\end{array}$ & 5-d procedure; 2-h EtOH access & {$[37]$} \\
\hline & $\begin{array}{l}\text { Baclofen (intra-VTA) } \uparrow 20 \% \mathrm{EtOH} \\
\text { consumption (intra-VTA) }\end{array}$ & 16-d procedure; 2-h EtOH access & {$[38]$} \\
\hline \multirow[t]{2}{*}{ Dopaminergic \& opioidergic } & $\begin{array}{l}\text { Naltrexone (i.p) and GBR } 12909 \text { (i.p) } \downarrow 20 \% \\
\text { EtOH consumption }\end{array}$ & 2-d procedure; 2-h EtOH access & {$[41]$} \\
\hline & $\begin{array}{l}\text { D2LR KO mice showed } \uparrow 20 \% \text { EtOH } \\
\text { consumption compared to WT mice }\end{array}$ & $\begin{array}{l}\text { 4-d procedure; 2-h EtOH access days 1-3, 4-h EtOH } \\
\text { access day } 4\end{array}$ & {$[42]$} \\
\hline \multirow[t]{2}{*}{ Nicotinic } & $\begin{array}{l}\text { Mecamylamine (i.p.), cytisine (i.p.), and } \\
\text { nicotine (i.p.) } \downarrow 20 \% \text { EtOH consumption }\end{array}$ & 2-d procedure; 2-h EtOH access & {$[47]$} \\
\hline & $\begin{array}{l}\text { Lobeline HCL (s.c.) } \downarrow 20 \% \text { EtOH } \\
\text { consumption }\end{array}$ & 2-d procedure; 4-h EtOH access & {$[48]$} \\
\hline Endocannabinoid & $\begin{array}{l}\text { WIN 55-313 (i.p.) dose-dependently } \\
\text { modulated } 20 \% \text { EtOH consumption; pVTA } \\
\text { administration altered the time course of } \\
\text { ethanol consumption }\end{array}$ & 7-d procedure; 2-h EtOH access & {$[31]$} \\
\hline \multirow[t]{4}{*}{$\mathrm{CRF}$} & $\begin{array}{l}\text { CP- } 154,526 \text { (i.p.) } \downarrow \text { binge-like } 20 \% \text { EtOH } \\
\text { consumption, but not low-level EtOH } \\
\text { consumption }\end{array}$ & $\begin{array}{l}\text { 4-d procedure; 4-h EtOH access days 1-4; 2-h EtOH } \\
\text { access days 1-3, 4-h EtOH access day } 4\end{array}$ & {$[52]$} \\
\hline & $\begin{array}{l}a \text {-helical } \mathrm{CRF}_{9-41} \text { (i.c.v.) and Ucn3 (i.c.v.) } \downarrow \\
20 \% \text { EtOH consumption }\end{array}$ & $\begin{array}{l}\text { 4-d procedure; 2-h EtOH access days 1-3, 4-h EtOH } \\
\text { access day } 4\end{array}$ & {$[53]$} \\
\hline & $\begin{array}{l}\text { Ucn1 (intra lateral septum) } \downarrow 20 \% \mathrm{EtOH} \\
\text { consumption }\end{array}$ & 3-d procedure; 2-h EtOH access & {$[54]$} \\
\hline & $\begin{array}{l}\text { CRF } 1 \text { KO and CRF KO mice show } \downarrow \text { binge- } \\
\text { like consumption of } 20 \% \text { EtOH relative to } \\
\text { WT mice }\end{array}$ & $\begin{array}{l}\text { 4-d procedure; 2-h EtOH access days 1-3, 4-h EtOH } \\
\text { access day } 4\end{array}$ & {$[55]$} \\
\hline Melanocortin & $\begin{array}{l}\text { AgRP KO mice showed } \downarrow \text { binge-like } 20 \% \\
\text { EtOH consumption relative to WT mice }\end{array}$ & $\begin{array}{l}\text { 4-d procedure; 2-h EtOH access days 1-3, 4-h EtOH } \\
\text { access day } 4\end{array}$ & {$[56]$} \\
\hline NPY & $\begin{array}{l}\text { NPY (i.c.v.), Y1R agonist (i.c.v.), and Y2R } \\
\text { antagonist (i.c.v.) } \downarrow 20 \% \text { EtOH consumption; } \\
\text { history of binge-like } 20 \% \text { EtOH consumption } \\
\text { altered NPY, Y1R, and Y2R } \\
\text { immunoreactivity in the CeA and } \uparrow \mathrm{NPY} \text { - } \\
\text { induced inhibition of GABAergic } \\
\text { transmission in slice preparations of CeA }\end{array}$ & $\begin{array}{l}\text { 4-d procedure; } 2-\mathrm{h} \text { EtOH access days } 1-3,4-\mathrm{h} \\
\text { access day } 4\end{array}$ & {$[29]$} \\
\hline \multirow[t]{2}{*}{ Ghrelin } & $\begin{array}{l}\text { Neither leptin (i.p.), ghrelin (i.p.), nor food } \\
\text { restriction altered } 20 \% \text { EtOH consumption }\end{array}$ & $\begin{array}{l}\text { 4-d procedure; 2-h EtOH access days 1-3, 4-h EtOH } \\
\text { access day } 4\end{array}$ & {$[30]$} \\
\hline & $\begin{array}{l}\text { D-Lys-3-GHRP-6 (i.p.) } \downarrow 20 \% \text { EtOH } \\
\text { consumption }\end{array}$ & $\begin{array}{l}\text { 7-d procedure; 2-hr EtOH access days 4-6, 4-hr } \\
\text { EtOH access day } 7\end{array}$ & {$[60]$} \\
\hline
\end{tabular}

(DID, drinking in the dark; $\downarrow$, decrease or attenuation; $\uparrow$, increase) 